\title{
Prospective Randomised Clinical Trial Evaluating the Effects of Two Different Implant Collar Designs on Peri-Implant Healing and Functional Osseointegration after 25 Years
}

Short Title: Peri-Implant Healing Around Different Machined-Collar Designs

Key Words: Bone-implant interactions, Clinical research/Clinical trials, Periodontology, Prosthodontics, Soft-tissue-implant interactions, Surface chemistry, Surgical techniques, Biomechanics/Finite element analysis

Running Head: Effects of Implant Collar Designs on Peri-Implant Healing

Camarda, Aldo Joseph, DDS MSc. Associate Professor, Département de stomatologie, Faculty of Dental Medicine, Université de Montréal, Pavillion Roger-Gaudry, Suite D-540, C. P. 6128, succursale Centre-ville, Montreal (QC), Canada, H3C 3J7, Telephone (514) 343-7124, Fax (514) 343-2233, aj.camarda@umontreal.ca (corresponding author).

Durand, Robert, DMD MSc. Associate Professor, Département de santé buccale, Faculty of Dental Medicine, Université de Montréal, Montreal (QC), Canada, H3C 3J7.

Benkarim, Marwa. Undergraduate student, Faculty of Dental Medicine, Université de Montréal, Montreal (QC), Canada, H3C 3J7.

Rompré, Pierre H. MSc. Research Associate, Faculty of Dental Medicine, Université de Montréal, Montreal (QC), Canada, H3C 3J7.

Guertin, Geneviève, DMD MSc. Associate Professor, Département de dentisterie de restauration, Faculty of Dental Medicine, Université de Montréal, Montreal (QC), Canada, H3C 3J7.

Ciaburro, Hugo, DMD MSc. Associate Professor, Département de dentisterie de restauration, Faculty of Dental Medicine, Université de Montréal, Montreal (QC), Canada, H3C 3J7. 


\title{
Prospective Randomised Clinical Trial Evaluating the Effects of Two Different Implant Collar Designs on Peri-Implant Healing and Functional Osseointegration after 25 Years
}

Key Words: Bone-implant interactions, Clinical research/Clinical trials, Periodontology, Prosthodontics, Soft-tissue-implant interactions, Surface chemistry, Surgical techniques, Biomechanics/Finite element analysis

\begin{abstract}
Objectives: Evaluate the effects of two different machined-collar lengths and designs on periimplant healing.
\end{abstract}

Material and Methods: An implant with a microtextured surface and 3.6mm-long internalconnection machined collar was compared to two implants that had an identical $1.2 \mathrm{~mm}$-long external-connection machined collar, but one had the microtextured surface while the other's was machined. Participants received the three implants, with microgap at the crest, alternately at five sites between mental foramen, and a full-arch prosthesis. Peri-implant bone levels were measured after 23 to 26 years of function. Keratinized tissue height, plaque, probing depth, bleeding, and purulence were also evaluated. Descriptive and mixed models for repeated-measures analyses were used, with Bonferroni correction for pairwise comparisons.

Results: Twenty-two participants (110 implants) were evaluated at the 25 -year examination. Microtextured implants with the longer machined collar had significantly greater mean marginal bone loss $(-1.77 \mathrm{~mm} \pm 0.18$, mean $\pm \mathrm{SE})$ than machined $(-0.85 \mathrm{~mm} \pm 0.18, p<.001)$ and microtextured $(-1.00 \pm 0.18 \mathrm{~mm}, p<.001)$ implants with the shorter machined collar. Keratinized tissue height was greater for internal-connection $(0.74 \mathrm{~mm} \pm 0.10)$ versus external-connection $(0.51 \pm 0.08, p=0.01)$ microtextured implants. No differences were observed for plaque $(p=0$ $.78)$, probing depth $(p=0.42)$, bleeding $(p=0.07)$, and purulence $(p=1.00)$. Implant survival rate was $99 \%$.

Conclusions: Implants with the $1.2 \mathrm{~mm}$ machined collar limited bone loss to $1 \mathrm{~mm}$, while those with the longer machined collar showed $>1.5 \mathrm{~mm}$ loss after 25 years of function with microgap at the crest. Internal-connection design and fixture surface microtexturing did not result in greater bone preservation.

ClinicalTrials.gov Identifier: NCT03862482. 


\section{Introduction}

Accepted benchmark criteria for a functionally successful, osseointegrated dental implant are based on results obtained with the machined, parallel-wall, platform-matched external-connection Brånemark® implant (Nobelpharma) (Adell, 1987; Albrektsson, \& Brånemark, et al., 1981; Albrektsson, \& Zarb, et al., 1986; Brånemark, 1983; Brånemark, 1987). These criteria include a maximum peri-implant bone loss of $1.2 \mathrm{~mm}$ after the first year of function, and not more than $0.1 \mathrm{~mm}$ loss annually thereafter. While countersinking and stage- 2 surgery and abutment connection contribute to initial bone loss (Adell, 1987), functional forces exerted at the implant/abutment interface microgap (MG) could eventually cause abutment loosening and mobility (Sutter, et al., 1993). If present, such mobility results in a widened MG, peri-abutment soft tissue inflammation, bacterial proliferation, infection, and bone loss, particularly if MG is located at the alveolar crest (Quirynen, \& van Steenberghe, 1993). Because these bacteria were identified in pockets around failing implants, a cause-and-effect relationship was considered (Becker, et al., 1990). As a result, new implant designs eliminate countersinking and increase resistance to functional forces, thus reducing the potential for abutment movement and bone loss. Screw-Vent ${ }^{\circledR}$ (Core-Vent, original manufacturer) is one such implant. Its narrower collar does not require countersinking, and its longer internal-connection, friction-fit collar design increases resistance to functional forces. Furthermore, its acid-etched fixture surface could enhance biological osseointegration. These factors should preserve more bone (Niznick, 1989). However, one short-term clinical study reported greater bone loss with this implant compared to Brånemark ${ }^{\circledR}$ and Swede-Vent ${ }^{\circledR}$ implants (De Bruyn, et al., 1992). Although the Swede-Vent ${ }^{\circledR}$ implant was a clone of the Brånemark® macro structure, its fixture surface was identically acid etched as that of the Screw-Vent ${ }^{\circ}$ implant by the same manufacturer. Because Screw-Vent ${ }^{\circledR}$ and Swede-Vent ${ }^{\circledR}$ had identically microtextured fixture surfaces, but Screw-Vent ${ }^{\circledR}$ showed the greatest short-term bone loss, the authors suggested that an implant's longer machined collar could cause greater bone loss, and advocated long-term studies. Therefore, the present study evaluated the effects on peri-implant bone and soft-tissue healing of the two different machinedcollar designs; i.e. the identical shorter and wider external-connection collar design of Brånemark ${ }^{\circledR}$ and Swede-Vent ${ }^{\circledR}$ implants versus the longer and narrower internal-connection, friction-fit collar design of the Screw-Vent ${ }^{\circledR}$ implant, with MG placed at the crest. 


\section{Material and Methods}

\section{Participants, and implant description}

Between 1993 and 1996, 58 of 60 eligible participants had been recruited into a prospective, randomised clinical trial. This trial had been peer reviewed, had received ethical approval (SMH Scientific Research Committee Certificate No. PROJECT-90-01), and had taken place at the Université de Montréal's Faculty of Dental Medicine and its affiliated hospital dental department. The present study includes data collected at the 25-year (24.6 \pm 0.19 years, mean \pm SE) follow-up of this within-subject trial (University of Montreal Ethics Committee Certificate No. CERC-19015-P, ClinicalTrials.gov Identifier: NCT03862482). All research procedures were performed in accordance with the Helsinki Declaration and its later amendments, and all participants signed informed consent documents prior to inclusion into this study. Article preparation followed CONSORT guidelines/checklist (Moher, et al., 2010), as per EQUATOR reporting guidelines for randomised clinical trials.

Standard Brånemark System ${ }^{\circledR}$, Swede-Vent ${ }^{\circledR}$ and Screw-Vent ${ }^{\circledR}$ two-piece, platform-matched implants had a parallel-wall fixture/screw macro structure, with pitch height $(0.6 \mathrm{~mm})$ and flange angle (60 degrees) starting below their collar (Figure 1) (Binon, et al., 1992; De Bruyn, et al., 1992; Helsingen, \& Lyberg, 1994; Niznick, 1989; Wennerberg, et al., 1993). Swede-Vent® was a clone of the Brånemark $®$ macro design (Binon, et al., 1992; Helsingen, \& Lyberg, 1994). It had an identical $1.2 \mathrm{~mm}$-long external-connection machined collar requiring countersinking to place its fixture/collar border $1.2 \mathrm{~mm}$ below, $0.6 \mathrm{~mm}$-long centrally located external connection above, and wider implant/abutment interface platform at the alveolar crest (De Bruyn, et al., 1992; Helsingen \& Lyberg, 1994; Wennerberg, et al., 1993). Brånemark® and Swede-Vent ${ }^{\circledR}$ received a two-piece, platform-matched, parallel-wall abutment/screw unit. While the Brånemark® fixture

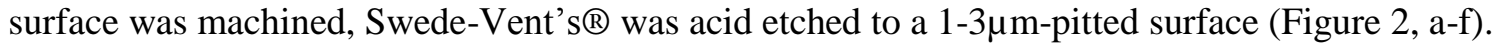
Although Swede-Vent ${ }^{\circledR}$ and Screw-Vent ${ }^{\circledR}$ fixtures were identically acid etched by the same manufacturer, Screw-Vent's ${ }^{\circledR}$ narrower 3.6mm-long machined collar did not require countersinking to place its fixture/collar border below and implant/abutment interface platform at the crest. In addition, Screw-Vent's ${ }^{\circledR}$ internal-connection, friction-fit collar design accepted a platform-matched, one-piece abutment/screw unit (De Bruyn, et al., 1992; Niznick, 1989). 


\section{Initial study design, surgical and prosthetic treatments}

A statistician had prepared a sampling design that included three configuration diagrams. Each diagram identified five implants of the three types, and showed how one of each type was to be placed in a cyclical, side-by-side, rotating fashion at five sites between mental foramen. In this way, an equal number of each implant type was to be placed at each of the five sites, and an equal number of participants received three of the five implants to the left or right of the midline. Configuration diagrams also documented each implant's length. Allocation concealment by the project coordinator then allowed 20 participants to receive Configuration 1, 19 had Configuration 2, and 19 had Configuration 3. Configuration diagram (but not number) was stored inside each chart, and only shown to the operating team at the time of surgery. The same surgeon (A.J.C.) placed all implants, in a submerged fashion, with MG at the crest. Implants were $3.75 \mathrm{~mm}$ in diameter, but the project coordinator determined implant length based on pre-operative radiographic measurements of available bone height. After approximately six months, the same surgeon exposed all implants, removed cover screws, and placed healing/prosthetic abutments. Complete seating of abutments onto implant platforms was confirmed with radiographs. Each participant received a conventional complete removable maxillary prosthesis and a fixed implantsupported mandibular prosthesis with bilateral posterior cantilever sections. Acrylic-resin teeth were processed over a casted, silver-palladium alloy framework. Gold prosthetic screws for Brånemark ${ }^{\circledR}$ and Swede-Vent ${ }^{\circledR}$ implants, and titanium screws for Screw-Vent ${ }^{\circledR}$ implants anchored the mandibular prostheses to the abutments. Participants followed an oral/implant hygiene regimen of daily mouthwash rinses, and gentle flossing and brushing with provided hygiene kits. Follow-ups occurred at one year, two years, 15 to 20 years, and 23 to 26 years following prostheses attachment. Twenty-two of the original participants $(41.5 \%$, age $71.1 \pm 1.2$ years, 11 women, 110 implants) were enrolled in the present 25-year study (Figure 3, Table 1).

\section{Clinical and radiographic evaluation}

At the 23- to 26-year recall, prosthodontists (H.C. and G.G.) ascertained the presence of any fractured or mobile prosthetic component. Following this assessment, the prosthodontists removed the prostheses, and abutment mobility was evaluated. Prosthesis and abutment mobility were evaluated by exerting manual pressure alternately on the handles of two instruments, each placed on opposite sides, and were recorded as absent (0) or present (1). Because abutment screws are tightened to $35 \mathrm{~N} / \mathrm{cm}$ of pressure using an instrument during prosthesis insertion, abutments should not be retrievable by finger pressure alone. Consequently, an attempt was also 
made to untighten each of the non-mobile abutments with finger pressure. If the abutment screw was retrievable, then the abutment was considered to be loose, even in the absence of visual mobility. Two calibrated examiners then performed the follow-up clinical (periodontist R.D.) and radiographic (M.B.) examinations, with abutments in place. All examiners were unaware of implant configurations. The dichotomous/binary plaque index (dPI) was used to document the absence (0) or presence (1) of plaque on the mesial, distal, buccal and lingual implant/abutment surfaces (Galgut, 1999). A ColorVue UNC12 Hu-Friedy probe was then used to measure (mm) the keratinized tissue height on the buccal and lingual implant/abutment surfaces, and probing depth on the mesial, distal, buccal and lingual implant/abutment surfaces. Intra-examiner agreement for 46 sites regarding keratinized tissue height and 100 sites for probing depth showed that $100 \%$ and $99 \%$ of measurements differed by $1 \mathrm{~mm}$ or less, respectively. Following probing, the dichotomous/binary bleeding index (dBI) documented the absence (0) or presence (1) of bleeding at each peri-implant site on the mesial, distal, buccal and lingual implant/abutment surfaces. (Galgut, 1999). Absence (0) or presence (1) of purulence was also documented.

After having assured the stability of all abutments, radiographic evaluation of quantitative periimplant bone healing was performed with the conventional peri-apical technique, using a standardized equipment and measurement protocol (Camarda, et al., 2018). Five peri-apical radiographs per participant were taken and numbered according to the implant site, 1 being the first on the subject's left, 5 the last on the right, and were stored in plastic film holders (Table 1). In order to compare and calibrate conventional peri-apical radiology with phosphor-plate technology, the Digora System ${ }^{\mathrm{TM}}$ (Digora Optime ${ }^{\mathrm{TM}}$, Sporedex Dental Co., Tuusula, Finland) was also used with the standardized equipment to take peri-apical radiographs on 95 implant/abutment units (Bhaskaran, et al., 2005). Following calibration, the distance between the first-bone-to-implant-contact-point and the crestal-microgap (fBIC-MG) was measured (mm) at the mesial and distal aspects of each implant/abutment unit using a Schei ruler under X10 magnification on the conventional films. Adobe Photoshop ${ }^{\circledR}$ (Adobe System Incorporated, San Jose, CA, USA) was used to measure fBIC-MG on the digital radiographs acquired with phosphor-plate technology. After having taken the radiographs, all abutments were removed and cleaned, and prosthesis/framework structures were cleaned and polished. Abutments and prosthesis/framework structures were then re-inserted using recommended instrument torque. Intraclass Correlation Coefficient (ICC, two-way mixed-effect model) assessed inter-examiner and intra-examiner reliability of bone level measurement on 20 radiographs. The reliability was 
excellent, with an inter-examiner ICC of 0.94 and an intra-examiner ICC of 1.00. The Dahlberg measurement error was $0.38 \mathrm{~mm}$.

\section{Statistical methods}

Assessment was initially based on intention-to-treat. However, based on a previous study (Camarda, et al., 2018), the effect size for the difference in bone level change between implant groups was expected to be 0.95 . A sample size of 16 participants would, therefore, ensure an $80 \%$ power to reject the null hypothesis, if it was indeed false at a two-sided Bonferroni-adjusted $\alpha$ level of 0.017 (to adjust for pairwise comparisons between implant groups), using a repeated measures ANOVA. Absence or presence of prosthesis, abutment, and implant mobility was analyzed with the Fisher's exact test. The mean keratinized tissue height $(\mathrm{mm})$, probing depth $(\mathrm{mm})$, and percentage of sites with $\mathrm{dPI}, \mathrm{dBI}$ and purulence were calculated for each implant. Shapiro-Wilk test was used to assess the normality of data distribution. These values were then analyzed with nonparametric ANOVA-type statistic for repeated measures within subject, with implant type, site and configuration as independent variables (Brunner, et al., 2002). Quantitative bone healing was analyzed with mixed models for repeated measures within subject, with implant type, site and configuration as independent variables, and implant length as covariate. The lengths of the different implant types were compared with a Kruskal-Wallis test. Confidence Interval (CI) was established at two-sided 95\% Confidence Level (CL). The level of significance was set at $p$ $<0.05$ and Bonferroni correction was applied for pairwise comparisons. ICC (two-way, mixedeffect model) and Bland-Altman limits of agreement (Bland, \& Altman, 1986) were used to analyze comparison of mean fBIC-MG values between conventional peri-apical radiology and phosphor-plate technology. All statistical analyses were performed using IBM SPSS Statistics for Windows ${ }^{\circledR}$ Version 25 (IBM Co., Armonk, NY, USA), and SAS 9.4 (SAS Institute, Cary, NC, USA).

\section{Results}

At the start of the trial, 60 participants (300 implants) had been assessed for eligibility. Fifty-eight participants had fulfilled all criteria, were randomly allocated to one of three implant configurations, and 290 mandibular implants were placed and restored. Two participants (10 implants) had been removed from the study, one for noncompliance, the other following a mandibular fracture with implant loss sustained during an accidental fall. Of the remaining 56 participants (280 implants), three (15 implants) had withdrawn from the study. As a result, 53 participants (265 implants) had presented for follow-up (49 after one year, 30 after two years, and 
21 after 15 to 20 years). At the present 25 -year ( $24.6 \pm 0.19$ years) period, two participants (10 implants) had deceased, 25 (125 implants) were untraceable, two (10 implants) were severely medically compromised and could not attend, and two (10 implants) refused to attend. Consequently, 22 participants $(41.5 \%$, age $71.1 \pm 1.2$ years, 11 women, 110 implants) were enrolled in the present study (Figure 3, Table 1). Sixteen (72.7\%) of the 22 participants had participated in the 15 - to 20 -year recall.

Implant survival rate was $99 \%$ overall and there was no mobility or fracture of all implantsupported prostheses at the 23- to 26-year follow-up (Table 2). Regarding mechanical complications, while there was no fracture of prosthetic screws, one screw had to be carefully removed using a high-speed hand piece. Following removal of prostheses, while there was no mobility, looseness or fracture of all internal-connection, friction-fit abutments, $11 \%$ of the external-connection abutments were mobile or loose. There was a significant difference for mean keratinized tissue height between Swede-Vent ${ }^{\circledR}(0.51 \pm 0.08 \mathrm{~mm})$ and Screw-Vent ${ }^{\circledR}(0.74 \pm$ $0.10 \mathrm{~mm}, p=0.01)$. Mean keratinized tissue height was $0.67 \pm 0.08 \mathrm{~mm}$ for Brånemark®. Implant site $(p=0.61)$ and configuration $(p=0.68)$ did not significantly influence keratinized tissue height. Mean probing depth was $2.09 \pm 0.14 \mathrm{~mm}$ for Brånemark®, $2.34 \pm 0.18 \mathrm{~mm}$ for SwedeVent ${ }^{\circledR}$, and $2.29 \pm 0.18 \mathrm{~mm}$ for Screw-Vent ${ }^{\circledR}$. Implant type $(p=0.42)$, site $(p=0.32)$, and configuration ( $p=0.71)$ did not significantly influence mean probing depth. There was no significant difference $(p=0.78)$ for mean $\mathrm{dPI}$ between Brånemark ${ }^{\circledR}(0.40 \pm 0.06)$, Swede-Vent ${ }^{\circledR}$ $(0.42 \pm 0.06)$, and Screw-Vent ${ }^{\circledR}(0.43 \pm 0.06)$. While implant type and configuration $(p=0.68)$ did not significantly influence dPI, implant site did, with para symphysis site $3(0.53 \pm 0.08)$ having significantly greater plaque accumulation than right distal site $5(0.30 \pm 0.06, p=.001)$. Mean dBI was $0.48 \pm 0.06$ for Brånemark ${ }^{\circledR}, 0.47 \pm 0.05$ for Swede-Vent ${ }^{\circledR}$, and $0.44 \pm 0.06$ for Screw-Vent ${ }^{\circledR}$. Implant type $(p=0.07)$, site $(p=0.32)$, and configuration $(p=0.17)$ did not significantly influence dBI. Purulence was documented for only one implant (Swede-Vent $\left.{ }^{\circledR}\right)$. Implant type $(p=1.00)$, site $(p=0.33)$, and configuration $(p=1.00)$ did not significantly influence purulence.

Radiographs showed bone surrounding an osseointegrated implant (Swede-Vent®) that had fractured at its fixture/collar border. The fractured portion and its abutment had been removed years previously, the implant-supported prosthesis had been acceptably modified, and there was no evidence of fixture infection or rejection. In addition, fBIC-MG levels could not be accurately measured for two implants (Brånemark ${ }^{\circledR}$ and Swede-Vent ${ }^{\circledR}$ ) due to technical issues encountered while taking or developing the radiographs. Consequently, 107 of the 110 implants were 
evaluated for quantitative bone healing (Figure 3, Table 3). Internal-connection, friction-fit, microtextured Screw-Vent ${ }^{\circledR}$ implants had significantly greater bone loss $(-1.77 \pm 0.18 \mathrm{~mm})$ than external-connection machined Brånemark $(-0.85 \pm 0.18 \mathrm{~mm}, p<.001)$ and microtextured Swede-Vent ${ }^{\circledR}$ implants $(-1.00 \pm 0.18 \mathrm{~mm}, p<.001)$. Brånemark ${ }^{\circledR}$ exhibited less bone loss than Swede-Vent ${ }^{\circledR}$, but this difference was not statistically significant $(p=1.00)$. While implant site $(p=0.06)$ and configuration $(p=0.43)$ did not significantly influence mean bone loss, implant length did $(p<.001)$. There were no statistically significant differences in implant length $(p=$ .145) between Brånemark $\AA\left(15.83 \pm 0.39 \mathrm{~mm}\right.$, min 10mm, max 20mm), Swede-Vent ${ }^{\circledR}(14.84 \pm$ $0.41 \mathrm{~mm}$, min $10 \mathrm{~mm}$, max $18 \mathrm{~mm})$, or Screw-Vent ${ }^{\circ}(14.42 \pm 0.33 \mathrm{~mm}$, min $10 \mathrm{~mm}, \max 16 \mathrm{~mm})$ implants. Therefore, for all implant types, longer implants had greater bone loss. In addition, $21.5 \%$ of all implants had bone loss $>2 \mathrm{~mm}$, and $59.1 \%$ of all participants had at least one implant with bone loss $>2 \mathrm{~mm}$. Descriptive analysis of peri-implant bone and soft-tissue periodontal parameters are presented in Table 4. Mean bone loss for all implant types was not greater $(p=$ 0.13 ) at the 23 - to 26 -year period compared to the 15 - to 20 -year period, being $-1.21 \pm 0.15 \mathrm{~mm}$ after 23 to 26 years and $-1.43 \pm 0.18 \mathrm{~mm}$ after 15 to 20 years. For mean fBIC-MG values, agreement between conventional radiology and phosphor-plate technology was excellent (ICC 0.93, CI 95\%, 0.89, 0.95; Bland-Altman limits of agreement 0.15, CI 95\%, $-1.21 \mathrm{~mm},+1.51 \mathrm{~mm}$ ). Therefore, the phosphor-plate imaging system was equivalent in terms of precision and validity to evaluate longitudinal peri-implant bone changes.

\section{Discussion}

Screw-Vent ${ }^{\circledR}$ was a new implant design with a microtextured $1-3 \mu$ m-pitted fixture surface that could enhance biological osseointegration, a narrower machined collar that does not require countersinking, and a longer internal-connection, friction-fit collar design that increases resistance to functional forces. Although these properties should be more advantageous for periimplant healing, one short-term clinical study reported greater crestal bone loss for Screw-Vent ${ }^{\circledR}$ compared to machined Brånemark® implants (De Bruyn, et al., 1992). This study also compared Screw-Vent ${ }^{\circledR}$ to Swede-Vent ${ }^{\circledR}$, a clone of the Brånemark ${ }^{\circledR}$ macro structure but its fixture surface was identically microtextured as that of Screw-Vent ${ }^{\circledR}$ by the same manufacturer. Because ScrewVent ${ }^{\circledR}$ and Swede-Vent ${ }^{\circledR}$ had identically-microtextured fixture surfaces but Screw-Vent ${ }^{\circledR}$ showed the greatest short-term bone loss, the authors proposed that Screw-Vent's longer collar was responsible for its greater bone loss, and advocated long-term studies. After 25 years of function with full arch, implant-supported mandibular prostheses, the present study confirms that the Screw-Vent ${ }^{\circledR}$ implant has the statistically significant greatest mean marginal bone loss 
compared to Brånemark $®$ and Swede-Vent ${ }^{\circledR}$ implants. Machined Brånemark ${ }^{\circledR}$ implants exhibit less bone loss than microtextured Swede-Vent ${ }^{\circledR}$ implants, but the difference is not statistically significant. This confirms results of previous comparative clinical studies regarding these three implants (Camarda, et al., 2018; De Bruyn, et al., 1992). However, before concluding that ScrewVent's ${ }^{\circledR}$ longer collar causes greater bone loss, as had been proposed, we must first consider how fixture surface microtexturing, countersinking, implant length, abutment mobility at crestal MG, and stage-2 surgery and abutment connection influence peri-implant healing in this study.

As discussed previously, Screw-Vent ${ }^{\circledR}$ and Swede-Vent ${ }^{\circledR}$ were clones of the Brånemark fixture macro design. However, while Brånemark $\AA$ is a machined implant, Screw-Vent ${ }^{\circledR}$ and SwedeVent ${ }^{\circledR}$ implants had identical 1-3 $\mu \mathrm{m}$-pitted fixture surfaces that were prepared by the same manufacturer. Because Brånemark® exhibits less mean bone loss than Swede-Vent ${ }^{\circledR}$, and ScrewVent ${ }^{\circledR}$ has the greatest bone loss of the three, microtexturing of the fixture surface does not lead to greater bone preservation. Moreover, while Brånemark® and Swede-Vent ${ }^{\circledR}$ require countersinking to place their identical, wider platforms at the crest, Screw-Vent's ${ }^{\circledR}$ narrower platform does not. Because Screw-Vent ${ }^{\circledR}$ has the greatest mean bone loss, elimination of countersinking does not lead to greater bone preservation. These findings agree with other longterm studies comparing internal-connection implants that have microtextured fixture and collar surfaces to the machined Brånemark® implant (Jacobs, et al., 2010; Ravald, et al., 2013). Regarding implant length, there is a significant, directly proportional relationship between length and mean bone loss for all implant types, with longer implants having greater bone loss. The covariate implant length corrects for this effect in the statistical analyses, and there are no statistically significant differences in implant lengths between implant types. Consequently, greater implant length cannot be the distinguishing feature that causes Screw-Vent's ${ }^{\circledR}$ significantly greatest bone loss compared to Brånemark ${ }^{\circledR}$ and Swede-Vent® .

Functionally-successful, osseointegrated, two-piece, submerged, external-connection implants placed with MG at the crest have a mean gingival index of 1.3 , mean plaque index of 0.8 , mean bleeding index of 0.6 , and mean probing depths varying between $3.8 \mathrm{~mm}$ and $3.9 \mathrm{~mm}$ (Cox, \& Zarb, 1987; Mombelli, et al., 1987). Therefore, abutment stability and oral hygiene procedures preserve peri-implant health (Hermann, et al., 2001). However, because these implants are less resistant to occlusal forces when compared with internal-connection implants, there is greater potential for abutment mobility, peri-abutment soft-tissue inflammation, bacterial colonization, infection, and bone loss (Callan, et al., 2005; Jansen, et al., 1997; Kitagawa, et al., 2005; Norton, 1997; Quirynen, et al., 1993; Sutter, et al., 1993). In such cases, these implants show a mean 
gingival index of 1.6, mean plaque index of 1.3, mean bleeding index of 2.0, and mean probing depths varying between 6mm and 8.5mm (Becker, et al., 1990; Mombelli, et al., 1987).

In this study, there is no mobility of all prostheses, and all implants examined at the 25 -year recall remain functionally osseointegrated. Following removal of prostheses, however, while there is no mobility or looseness of all Screw-Vent ${ }^{\circledR}$ internal-connection, friction-fit abutments, almost $11 \%$ of the Brånemark ${ }^{\circledR}$ and Swede-Vent ${ }^{\circledR}$ external-connection abutments exhibit some degree of abutment mobility or looseness. This supports previous comparative studies reporting that internal-connection, friction-fit collar designs better resist forces at implant/abutment interface, thereby lessening the potential for prosthesis and abutment movement, infection, and bone loss (Jansen, et al., 1997; Kitagawa, et al., 2005; Norton, 1997; Sutter, et al., 1993). However, in this study, while the internal-connection, friction-fit Screw-Vent ${ }^{\circledR}$ implants may contribute to prosthesis stability, they exhibit the greatest mean bone loss compared to the external-connection Brånemark ${ }^{\circledR}$ and Swede-Vent ${ }^{\circledR}$ implants. Moreover, for all implant types, participants have an average oral hygiene with approximately $40 \%$ mean dPI and dBI. Although all implants exhibit $<2 \mathrm{~mm}$ mean keratinized tissue height, their mean peri-implant probing depth is $<2.5 \mathrm{~mm}$, and purulence is found around only one implant (Swede-Vent $\left.{ }^{\circledR}\right)$. As a result, using the most recent definition of peri-implantitis recommended by the American Academy of Periodontology and the European Federation of Periodontology (Berglundh, et al., 2018), the participant-level prevalence for peri-implantitis in this study is $9 \%$ ( 2 out of 22 participants). This prevalence is less than the peri-implantitis prevalence of $29.7 \%$ and $16 \%$ reported in two long-term studies of edentulous participants, rehabilitated with implant-supported mandibular prostheses (Meijer, et al., 2014; Roos-Jansåker, et al., 2006). Consequently, the long-term peri-implant periodontal parameters in this study are well within accepted values for functionally successful, osseointegrated two-piece implants placed with MG at the crest (Table 4). Given the absence of prosthesis mobility and presence of acceptable peri-implant soft-tissue periodontal parameters, abutment mobility at crestal MG could not be the cause of this bone loss.

If two-piece, platform-matched implants are placed with their MG at the alveolar crest, there is a $1.5 \mathrm{~mm}$ mean marginal peri-implant bone loss (Hermann, et al., 1997). Interestingly, this consistent amount of bone loss occurs approximately four weeks following abutment connection, whether the implants are placed in a two-stage submerged or one-stage non-submerged fashion (Hermann, Buser, et al., 2000; Hermann, Cochan, et al., 2000). Therefore, it is the timing of the abutment connection, and not the stage- 2 surgery, that causes soft-tissue inflammation at crestal MG, with subsequent marginal bone loss. This inflamed tissue then migrates from the crest to a 
lower non-inflamed area, where a healthy, protective implant-gingival barrier, or biological width (BW), re-attaches onto the machined collar, closer to the implant's rough/smooth border (Cochran, Hermann, et al., 1997; Cochran, Simpson, et al., 1994; Weber, et al., 1996; Schroeder, et al., 1981). These findings are associated with two-piece implants that have a $1.5 \mathrm{~mm}$-long machined collar. On the other hand, a sufficiently rough fixture surface promotes bone attachment (Brunette, 1998; Bowers, et al., 1992; Buser, et al., 1991; Carlsson, et al., 1988; Kieswetter, et al., 1996; Klokkevold, et al., 1997; Thomas, \& Cook, 1985; Wennerberg, et al., 1996; Wilke, et al., 1985). Therefore, reducing the machined collar height would result in bone growth closer to the alveolar crest where the MG is located (Hämmerle, et al., 1996;Tan, et al., 2011). More specifically, reducing this height to $<1.5 \mathrm{~mm}$ results in less bone loss required for BW re-attachment following abutment connection (Hermann, et al., 2001; Quirynen, et al., 1992). In this regard, an in vivo study compared marginal bone healing between submerged, two-piece, platform-matched implants whose fixture/collar border was placed below and MG at the crest (Al-Sayyed, et al., 1994). These two implants were identical except that they had different machined-collar lengths $(0.75 \mathrm{~mm}$ versus $1.8 \mathrm{~mm})$. After four months, mean marginal bone loss stabilized at $-0.75 \mathrm{~mm}$ for the implants with the $0.75 \mathrm{~mm}$ collar, while significantly greater loss continued at nine months for the implants with the $1.8 \mathrm{~mm}$ collar. Another in vivo study compared marginal bone healing between two-piece implants placed with their MG at the crest (Weng, et al., 2010). One implant had a $0.75 \mathrm{~mm}$-long machined collar, the other a $1.5 \mathrm{~mm}$-long machined collar. Although not statistically significant according to the authors, the implant with the $0.75 \mathrm{~mm}$ collar had a mean fBIC-MG value of $-0.98 \mathrm{~mm}$ compared to $-2.08 \mathrm{~mm}$ for the implant with the $1.5 \mathrm{~mm}$ collar. In the present study, all implants were placed in a submerged fashion with their MG located at the alveolar crest. Research shows that after five years of function with twopiece implants, MG at the crest does not adversely affect peri-implant bone healing (Heijddenrijk, et al., 2006). While the Brånemark ${ }^{\circledR}$ and Swede-Vent ${ }^{\circledR}$ implants with the $1.2 \mathrm{~mm}$-long machined collar limit mean marginal bone loss to $1 \mathrm{~mm}$, the Screw-Vent ${ }^{\circledR}$ implants with the $3.6 \mathrm{~mm}$-long machined collar show $>1.5 \mathrm{~mm}$ bone loss after 25 years of function. Therefore, an implant's machined collar length seems to be more important than microtexturing $(1-3 \mu \mathrm{m})$ of the fixture surface, and/or friction-fit, internal connection implant design to preserve peri-implant bone in the long-term. Well-controlled, prospective, long-term studies are required to confirm this finding.

Comparison of mean fBIC-MG values for all implant types in this trial shows no statistically significant difference between the one-year and two-year follow-up periods (Camarda, et al., 2018). This represents an expected short-term, steady-state phase of osseous healing in the 
ongoing process of functionally successful osseointegration (Åstrand, et al., 2004). While there is greater mean bone loss between the one-year and 15- to 20-year periods, total cumulative bone loss is well within the acceptable value for ongoing functionally successful osseointegration (Albrektsson, 1986). There is, however, no significant difference in quantitative bone healing values for all implant types between the 15 - to 20 -year and 23 - to 26-year periods. The overall mean bone loss for all implants combined is $-1.43 \pm 0.18 \mathrm{~mm}$ after 15 to 20 years and $-1.21 \pm$ $0.15 \mathrm{~mm}$ after 23 to 26 years, resulting in a difference of $0.22 \mathrm{~mm}$ which is not statistically significant $(p=0.13)$. This difference is within the Dahlberg measurement error of $0.38 \mathrm{~mm}$. Moreover, precise visual evaluation of bone levels around dental implants is limited to $0.2 \mathrm{~mm}$, beyond which precise measurements cannot be assured (Geraets, \& Zhang, et al., 2014). Consequently, the difference in bone level measurements between the 15- to 20- and 23- to 26year periods in the present study is within the limits of the measurement method and can be considered as having occurred by chance.

Because a search of the scientific literature does not identify any similar 25-year clinical study of ongoing functional osseointegration, this unexpected finding cannot be supported or refuted. In fact, implantology research focuses primarily on discovering techniques that promote mechanical and/or biological osseointegration over the short-term. In this respect, some research has shown that when an acceptable, controlled occlusal force is applied to a freshly placed implant, the result is a below-threshold, peri-implant micro motion that is favorable to bone remodelling (Berglundh, et al., 2005; Brunski, 1999; Szmukler-Montcler, et al., 1998). However, if the degree of micro motion is above this threshold level of $150 \mu \mathrm{m}$, then fibrous encapsulation occurs and the implant fails to osseointegrate (Szmukler-Montcler, et al., 1998). Finite element analysis (FEA), an appropriate method to evaluate micro motion of a freshly placed three-dimensional implant model at the laboratory level (Li, et al., 2019; Limbert, et al., 2010), shows that this micro motion occurs along the entire length of the implant/bone interface (Winter, et al., 2013). Furthermore, sufficient bone density seems to play an important role in this process (Karl, \& Graef, et al., 2015; Karl, \& Palarie, et al., 2018). However, these factors do not apply to a functionally successful, osseointegrated implant. In this case, FEA shows that when a normal axial biting force of $200 \mathrm{~N}$ (Carr, \& Laney, 1987) is exerted on a three-dimensional osseointegrated implant model, the result is a below-threshold micro motion of $0.75 \mu \mathrm{m}$ located at the cervical level only of the implant/bone interface (Winter, et al., 2013). This degree of cervical peri-implant micro motion could cause bone remodelling in the form of bone stability or apposition (Isidor, 2006). On this point, radiographic evaluation of long-term peri-implant bone healing documents increased bone 
density of up to $8.2 \%$ around Astra Tech TiOblast ${ }^{\circledR}$ (Astra Tech, Mölndal, Sweden) and 7.7\% around Brånemark ${ }^{\circledR}$ two-piece implants placed between mental foramen, with $\mathrm{MG}$ at the crest, and restored with full-arch prostheses (Jacobs, et al., 2010). Therefore, acceptable occlusal forces causing a below-threshold peri-implant micro motion at the cervical level of functionally successful, osseointegrated implants could be an important factor that eventually results in a longterm, steady-state phase of osseous healing in the ongoing process of functional osseointegration. This could explain the finding that there is no statistically significant difference in bone loss between the 15- to 20-year and 23- to 26-year periods in this study. Long-term research is warranted regarding this possibility.

\section{CONCLUSIONS}

Implants with the $1.2 \mathrm{~mm}$-long machined collar limit mean marginal bone loss to $1 \mathrm{~mm}$, while those with the longer machined collar have $>1.5 \mathrm{~mm}$ loss. Within the limitations of this study, a parallel-wall, two-piece implant design with a $1.2 \mathrm{~mm}$-long machined collar, placed with implant/abutment MG at the crest, limits marginal bone loss to $1 \mathrm{~mm}$ after 25 years of function. Microtexturing $(1-3 \mu \mathrm{m})$ of the fixture surface and internal-connection, friction-fit collar design do not result in significantly greater bone preservation. Well-controlled, prospective, long-term studies are required to confirm these findings.

The authors report no conflict of interest. 
Figure 1

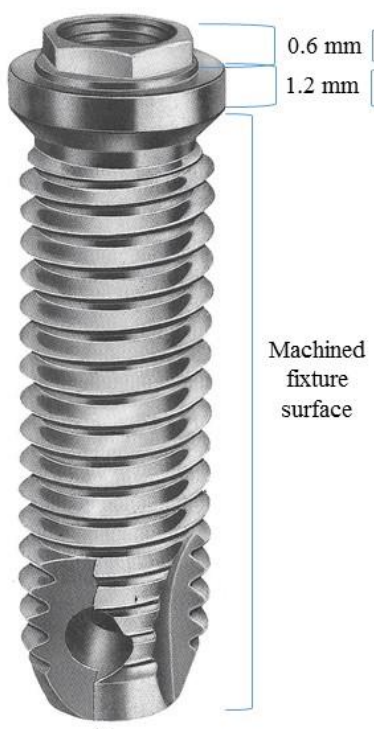

B

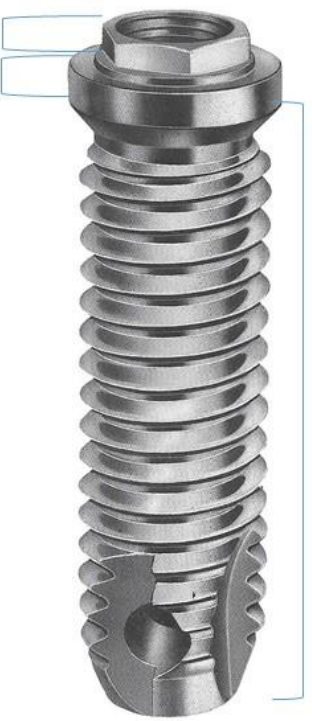

SW

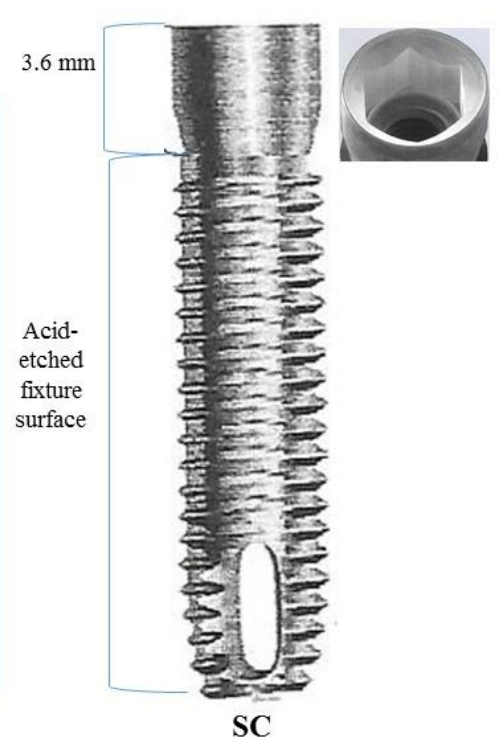

Implant types: B Brånemark® 3.75mm width, machined fixture surface, 1.2mm-long external-connection machined collar; SW Swede-Vent ${ }^{\circ}$ clone $3.75 \mathrm{~mm}$ width, fixture surface uniformly acid etched to $1-3 \mu \mathrm{m}, 1,2 \mathrm{~mm}$-long external connection machined collar; SC Screw-Vent ${ }^{\circledR} 3.75 \mathrm{~mm}$ width, fixture surface identically acid etched as that of SwedeVent ${ }^{\circledR}$ by the same manufacturer, 3.6mm-long internal-connection, friction-fit machined collar. Reproduced from Camarda et al., 2018 with permission from Quintessence International, Berlin, Germany 
Figure 2
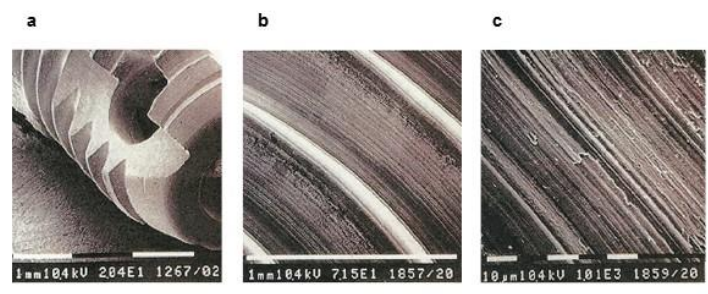

d

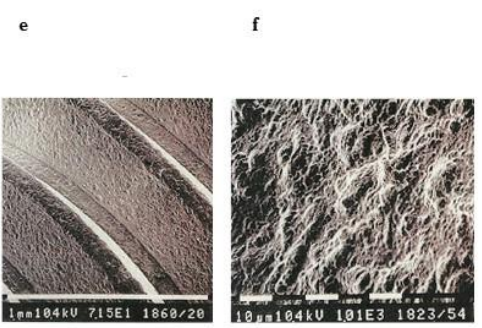

Implant types: a low magnification (x 18), b low magnification (x 72), c high magnification (x 1,010) scanning electron micrographs of Brånemark ${ }^{\circledR}$ implant; $d$ low magnification (x 18), e low magnification (x 72), f high magnification (x 1,010) scanning electron micrographs of Swede-Vent ${ }^{\circledR}$ implant (from Helsingen, \& Lyberg, 1994). Reproduced from Camarda et al., 2018 with permission from Quintessence International, Berlin, Germany 
Figure 3

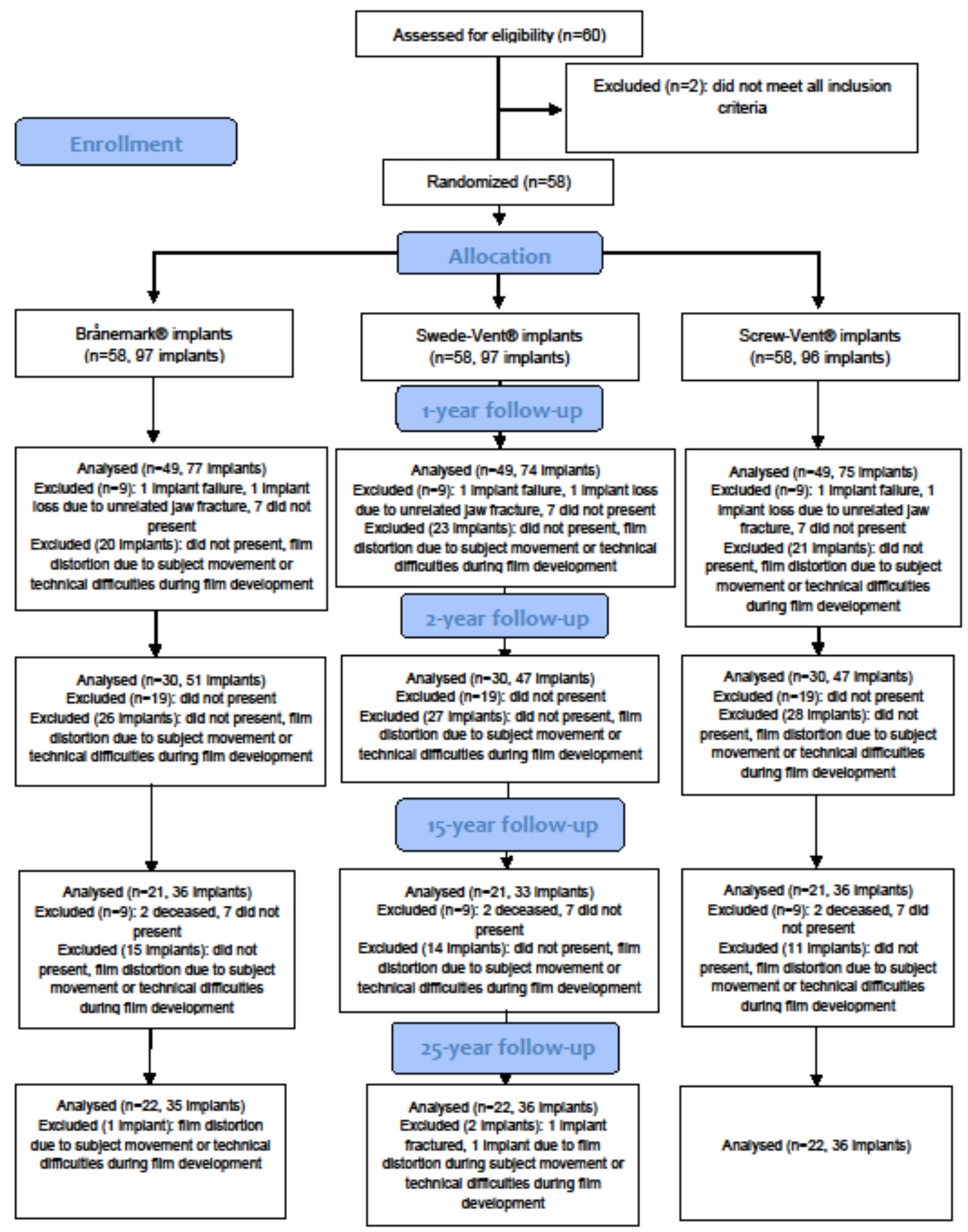

CONSORT Flow Diagram 


\begin{tabular}{|c|c|c|c|c|c|c|}
\hline & $\begin{array}{c}\text { Participant's } \\
\text { right }\end{array}$ & & & & $\begin{array}{c}\text { Participant's } \\
\text { left }\end{array}$ & \\
\hline $\begin{array}{c}\text { Configuration } \\
\text { number }\end{array}$ & $\begin{array}{c}\text { Site 5 } \\
\text { Right distal }\end{array}$ & $\begin{array}{c}\text { Site 4 } \\
\text { Right } \\
\text { medial }\end{array}$ & $\begin{array}{c}\text { Site 3 } \\
\text { Para } \\
\text { symphysis }\end{array}$ & $\begin{array}{c}\text { Site 2 } \\
\text { Left } \\
\text { medial }\end{array}$ & $\begin{array}{c}\text { Site l } \\
\text { Left distal }\end{array}$ & $\begin{array}{c}\text { Total } \\
\text { Participants } \\
\text { (Implants) }\end{array}$ \\
\hline 1 & B & SW & SC & B & SW & $\begin{array}{c}8 \\
(40)\end{array}$ \\
\hline 2 & SW & $\overline{\mathrm{SC}}$ & $\bar{B}$ & SW & $\overline{\mathrm{SC}}$ & $\begin{array}{c}8 \\
(40)\end{array}$ \\
\hline 3 & SC & B & SW & SC & B & $\begin{array}{c}6 \\
(30)\end{array}$ \\
\hline Total & & & & & & $\begin{array}{c}22 \\
(110)\end{array}$ \\
\hline
\end{tabular}




\begin{tabular}{|c|c|c|c|c|c|c|}
\hline \multicolumn{2}{|c|}{ Table 2. Life-table analysis of overall implant survival. } \\
\hline $\begin{array}{c}\text { Interval } \\
\text { (years) }\end{array}$ & $\begin{array}{c}\text { Number } \\
\text { entering } \\
\text { interval }\end{array}$ & $\begin{array}{c}\text { Number } \\
\text { withdrawing } \\
\text { during } \\
\text { interval }\end{array}$ & $\begin{array}{c}\text { Number } \\
\text { exposed to } \\
\text { risk }\end{array}$ & $\begin{array}{c}\text { Number of } \\
\text { failures }\end{array}$ & $\begin{array}{c}\text { Interval } \\
\text { survival } \\
\text { rate (\%) }\end{array}$ & $\begin{array}{c}\text { Cumulative } \\
\text { survival rate } \\
\text { (\%) }\end{array}$ \\
\hline 0 & 290 & 25 & 277.5 & 2 & 99 & 99 \\
\hline 1 & 263 & 47 & 239.5 & 0 & 100 & 99 \\
\hline 2 & 216 & 81 & 175.5 & 0 & 100 & 99 \\
\hline 15 & 135 & 25 & 122.5 & 0 & 100 & 99 \\
\hline 25 & 110 & 110 & 55.0 & 0 & 100 & 99 \\
\hline
\end{tabular}




\begin{tabular}{|c|c|c|c|c|c|}
\hline $\begin{array}{l}\text { Time (years } \\
\text { after } \\
\text { prostheses } \\
\text { insertion) }\end{array}$ & $\begin{array}{c}\text { Brånemark }{ }^{\circledR} \\
\text { (B) }\end{array}$ & $\begin{array}{l}\text { Swede-Vent }{ }^{\circledR} \\
\text { (SW) }\end{array}$ & $\begin{array}{l}\text { Screw-Vent }{ }^{\circledR} \\
\text { (SC) }\end{array}$ & Mean difference $(95 \% \mathrm{CI})$ & $p^{*}$ \\
\hline $\begin{array}{c}1 \\
49 \text { participants } \\
\text { B (77 implants) } \\
\text { SW (74 implants) } \\
\text { SC (75 implants) }\end{array}$ & $\begin{array}{c}-1.00 \pm 0.12 \\
(-1.23,-0.77)\end{array}$ & $\begin{array}{c}-0.71 \pm 0.11 \\
(-0.94,-0.48)\end{array}$ & $\begin{array}{c}-1.39 \pm 0.12 \\
(-1.62,-1.16)\end{array}$ & $\begin{array}{l}\text { B-SC: } 0.39(0.09,0.69) \\
\text { B-SW: }-0.29(0.59,0.01) \\
\text { SC-SW: }-0.68,(-0.98,-0.39)\end{array}$ & $\begin{array}{c}.006 \\
.059 \\
<.001\end{array}$ \\
\hline $\begin{array}{c}2 \\
30 \text { participants } \\
\text { B (51 implants) } \\
\text { SW (47 implants) } \\
\text { SC (47 implants) }\end{array}$ & $\begin{array}{c}-0.99 \pm 0.13 \\
(-1.26,-0.72)\end{array}$ & $\begin{array}{c}-0.82 \pm 0.14 \\
(-1.09,-0.55)\end{array}$ & $\begin{array}{c}-1.55 \pm 0.13 \\
(-1.82,-1.28)\end{array}$ & $\begin{array}{l}\text { B-SC: } 0.56(0.26,0.85) \\
\text { B-SW: }-\mathbf{0 . 1 7}(-0.47,0.13) \\
\text { SC-SW: }-\mathbf{0 . 7 3}(-1.02,-0.43)\end{array}$ & $\begin{array}{l}<.001 \\
.495 \\
<.001\end{array}$ \\
\hline $\begin{array}{c}15-20 \\
21 \text { participants } \\
\text { B (36 implants) } \\
\text { SW (33 implants) } \\
\text { SC (36 implants) } \\
\end{array}$ & $\begin{array}{c}-1.08 \pm 0.20 \\
(-1.49,-0.67)\end{array}$ & $\begin{array}{c}-1.28 \pm 0.20 \\
(-1.69,-0.87)\end{array}$ & $\begin{array}{c}-1.92 \pm 0.20 \\
(-2.33,-1.51)\end{array}$ & $\begin{array}{l}\text { B-SC: } 0.83(0.45,1.22) \\
\text { B-SW: } 0.20(-0.19,0.59) \\
\text { SC-SW: }-0.64(-1.01,-0.26)\end{array}$ & $\begin{array}{l}<.001 \\
.662 \\
<.001\end{array}$ \\
\hline $\begin{array}{c}23-26 \\
22 \text { participants } \\
\text { B (35 implants) } \\
\text { SW (36 implants) } \\
\text { SC (36 implants) }\end{array}$ & $\begin{array}{c}-0.85 \pm 0.18 \\
(-1.22,-0.49)\end{array}$ & $\begin{array}{c}-1.00 \pm 0.18 \\
(-1.35,-0.64)\end{array}$ & $\begin{array}{c}-1.77 \pm 0.18 \\
(-2.13,-1.41)\end{array}$ & $\begin{array}{l}\text { B-SC: } 0.92(0.50,1.34) \\
\text { B-SW: } 0.14(-0.26,0.55) \\
\text { SC-SW: }-0.77(-1.16,-0.38)\end{array}$ & $\begin{array}{l}<.001 \\
1.000 \\
<.001\end{array}$ \\
\hline
\end{tabular}

*Bonferroni-adjusted $p$ values are shown. 
Table 4. Descriptive analysis of bone loss, dPI, and dBI after 25 years. Four sites (mesial, distal, buccal, and lingual) were used to measure dPI and dBI for each implant/abutment unit.

\begin{tabular}{|l|l|}
\hline \hline & $\%(\mathbf{n})$ \\
\hline Bone loss & \\
Implants with bone loss >2 mm & $21.5 \%(23 / 107)$ \\
Participants with 1 implant or more with bone & $59.1 \%(13 / 22)$ \\
loss >2 mm & \\
\hline dPI: yes/no at 4 sites for each implant & \\
Implants with 0 site with plaque & $25.7(28 / 109)$ \\
Implants with 1 site with plaque & $22.9(25 / 109)$ \\
Implants with 2 sites with plaque & $24.8(27 / 109)$ \\
Implants with 3 sites with plaque & $12.8(14 / 109)$ \\
Implants with 4 sites with plaque & $13.8(15 / 109)$ \\
\hline dBI: yes/no at 4 sites for each implant & \\
Implants with 0 site with bleeding & $20.2(22 / 109)$ \\
Implants with 1 site with bleeding & $22.0(24 / 109)$ \\
Implants with 2 sites with bleeding & $21.1(23 / 109)$ \\
Implants with 3 sites with bleeding & $24.8(27 / 109)$ \\
Implants with 4 sites with bleeding & $11.9(13 / 109)$ \\
\hline
\end{tabular}




\section{References}

Adell, R. (1987). Long-term treatment results. In: Brånemark, P-I., Zarb, G.A., Albrektsson, T. (Eds.). Tissue-integrated prostheses: osseointegration in clinical dentistry (pp. 175-285). Quintessence Publishing Co. Inc.

Albrektsson, T., Brånemark. P-I., Hansson, H. A., \& Lindström, J. (1981). Osseointegrated titanium implants. Requirements for insuring a long-lasting, direct bone-to-implant anchorage. Acta Scandinavia, 52, 155-170. https://doi:10.3109/17453678108991776

Albrektsson, T., Zarb, G. A., Worthington, P., \& Eriksson, A. (1986). The long-term efficacy of currently used dental implants: a review and proposed criteria of success. The International Journal of Oral and Maxillofacial Implants, 1, 11-25. PMID: 3527955.

Al-Sayyed, A., Deporter, D. A., Pilliar, R.M., Watson, P. A., Pharaoh, M., Berhane, K., \& Carter, S. (1994). Predictable crestal bone remodelling around two porous-coated titanium alloy dental implant systems. A radiographic study in dogs. Clinical Oral Implants Research, 5, 131-141. https://doi:10.1034/j.1600-0501.1994.050303.x

Åstrand, P., Engquist, B., Dahlgren, S., Gröndahl, K., Engquist, E., \& Feldman, H. (2004). Astra Tech and Brånemark System implants: a 5-year prospective study of marginal bone reactions. Clinical Oral Implants Research, 15, 413-420. https://doi:10.1111/j.1600-0501.2004.01028.x Becker, W., Becker, B. E., Newman, M. G., \& Nyman, S. (1990). Clinical and microbiological findings that may contribute to dental implant failure. The International Journal of Oral and Maxillofacial Implants, 5, 31-38. PMID: 2391137.

Berglundh, T., Abrahamsson, I., \& Lindhe, J. (2005). Bone reactions to longstanding functional load at implants: An experimental study in dogs. Journal of Clinical Periodontology, 32, 925 932. https://doi:10.1111/j.1600-051X.2005.00747.x

Berglundh, T., Armitage, G., Araujo, M. G., Avila-Ortiz, G., Blanco, J., Camargo, P. M., Chen, S., Cochran, D., Derks, J., Figuero, E., Hämmerle, C. H. F., Heitz-Mayfield, L. J. A., Huynh-Ba, G., Iacono, V., Koo, K. T., Lambert, F., McCauley, L., Quirynen, M., Renvert, S., (...), \& Zitzmann, N. (2018). Peri-implant Diseases and Conditions: Consensus Report of Workgroup 4 of the 2017 World Workshop on the Classification of Periodontal and Peri-Implant Diseases and Conditions. Journal of Clinical Periodontology, 45, Suppl 20:S286-S291.

https://doi:10.1111/'jcpe.12957 
Bhaskaran, V., Qualtrough, A. J. E., Rushton, V. E., Worthington, H. V., \& Horner, K. (2005). A laboratory comparison of three imaging systems for image quality and radiation exposure characteristics. International Endodontic Journal, 38, 645-652. https://doi.org/10.1111/j.13652591.2005.00998.x

Binon. P. P, Weir, D. J., \& Marshall, S. J. (1992). Surface analysis of an original Brånemark implant and three related clones. The International Journal of Oral and Maxillofacial Implants, 7 , 168-195. PMID: 1398833.

Bland, J. M., \& Altman, D.G. (1986). Statistical methods for assessing agreement between two methods of clinical measurement. Lancet, Feb (8), 1, 8476, 307-310.

Bowers, K. T., Keller, J. C., Randolph, B. A., Wick, D. G., \& Michaels, C. M. (1992). Optimization of surface micromorphology for enhanced osteoblast responses in vitro. The International Journal of Oral and Maxillofacial Implants, 7, 302-310. PMID: 1289255.

Brånemark, P-I. (1983). Osseointegration and its experimental background. The Journal of Prosthetic Dentistry, 50(3), 399-410.

Brånemark P-I. (1987). Introduction to osseointegration. In Brånemark, P-I., Zarb, G.A., Albrektsson, T. (Eds.). Tissue-integrated prostheses: osseointegration in clinical dentistry (pp. 11-76). Quintessence Publishing Co. Inc.

Brunette, D. M. (1998). The effects of implant surface topography on the behaviour of cells. The International Journal of Oral and Maxillofacial Implants, 3, 231-246. PMID:3075965.

Brunner, E., Domhof, S., \& Langer. F. (2002). Nonparametric analysis of longitudinal data in factorial experiments. J.Wiley.

Brunski, J. B. (1991). In vivo bone response to biomechanical loading at the bone/dental implant interface. Advances in Dental Research, 3 (1), 99-119.

https://doi.org/10.1177/08959374990130012301

Buser, D., Schenk, R. K., Steinemann, S., Fiorinelli, J. P., Fox, C. H., \& Stitch, H. (1991).

Influence of surface characteristics on bone integration of titanium implants. A histomorphometric study in miniature pigs. Journal of Biomedical Research, 25, 889-902. https://doi:10.1002/jbm.820250708 
Callan, D. P., Cobb, C. M., \& Williams K. B. (2005). DNA probe identification of bacteria colonizing internal surfaces of the implant-abutment interface: a preliminary study. Journal of Periodontology, 76, 115-120. https://doi:10.1902/jop.2005.76.1.115

Camarda, A. J., Milot, P., Ciaburro, H., Rompré, P., Sallaleh, I., \& Do, C. M. A. (2018). Longterm randomized clinical trial evaluating the effects of fixture surface acid-etching and machined collar design on bone healing. Quintessence International, Oct; 49 (9): 733 - 743. https://doi:10.3290/j.qi.a41013

Carlsson, L., Röstlund, T., Albrektsson, B., \& Albrektsson, T. (1988). Removal torques for polished and rough titanium implants. The International Journal of Oral and Maxillofacial Implants, 3, 21-24. PMID:3250932.

Carr, A. B., \& Laney, W. R. (1987). Maximum occlusal force levels in patients with osseointegrated oral implant prostheses and patients with complete dentures. The International Journal of Oral and Maxillofacial Implants, 2(2), 101-108. PMID: 3325414.

Cochran, D. L., Hermann, J. S., Schenk, R. K., Higginbottom, F., \& Buser, D. (1997). Biologic width around titanium implants. A histomorphometric analysis of the implanto-gingival junction around unloaded and loaded nonsubmerged implants in the canine mandible. Journal of Periodontology, 68, 186-198. https://doi:10.1902/jop.1997.68.2.186

Cochran, D.L., Simpson, J., Weber, H. P., \& Buser D. (1994). Attachment and growth of periodontal cells on smooth and rough titanium. The International Journal of Oral and Maxillofacial Implants, 289-297. PMID:29624192.

Cox, J. F., \& Zarb, G. A. (1987). The longitudinal clinical efficacy of osseointegrated dental implants: a 3-year report. The International Journal of Oral and Maxillofacial Implants, 2, 91100. PMID: 3325416.

De Bruyn, H., Collaert, B., Lindén, U., \& Flygare L. (1992). A comparative study of the clinical efficacy of Screw-Vent implants versus Brånemark fixtures, installed in a periodontal clinic. Clinical Oral Implants Research, 3, 32-41.

Galgut, P. (1999). A comparison of different indices used in the clinical assessment of plaque and gingival bleeding. Clinical Oral Investigations, June, 3(2), 96-99.

https://doi:10.1007/s007840050085 
Geraets, W., Zhang, L., Liu, Y., \& Wismeijer, D. (2014). Annual bone loss and success rates of dental implants based on radiographic measurement. Dentomaxillofac Radiol, 43, 7, 20140007. https://doi:10.1259/dmfr.20140007

Hämmerle, C. H. F., Brägger, U., Bürgen, W., \& Lang, N. P. (1996). The effect of subcrestal placement of the polished surface of ITI® implants on marginal soft and hard tissues. Clinical Oral Implants Research, 7, 111-119. https://doi:10.1034/j.1600-0501.1996.070204.x

Heijddenrijk, K., Raghoebar, G. M., Meijer, H. J. A., Stegenga, B., \& van der Reijden, Wil A. (2006). Feasibility and influence of the microgap of two-piece implants placed in a nonsubmerged or submerged procedure: A five-year follow-up clinical trial. Journal of Periodontology, 77, 1051-1060. https://doi:10.1902/jop.2006.050342.

Helsingen, A. L. \& Lyberg, T. (1994). Comparative surface analysis and clinical performance studies of Brånemark implants and related clones. The International Journal of Oral and Maxillofacial Implants, 9, 422-430.

Hermann, J. S., Buser, D., Schenk, R. K., \& Cochran, D. L. (2000). Crestal bone changes around titanium dental implants. A histometric evaluation of unloaded non-submerged and submerged implants in the canine mandible. The Journal of Periodontology, 71(9), 1412-1424.

https://doi:10.1902/jop.2000.71.9.1412

Hermann, J. S., Cochran, D. L., Nummikoski, P. V., \& Buser. D. (1997). Crestal bone changes around titanium implants. A radiographic evaluation of unloaded nonsubmerged and submerged implants in the canine mandible. Journal of Periodontology, 68, 1117-1130.

https://doi:10.1902/jop.1997.68.11.1117

Hermann, J. S., Schoolfield, J. D., Schenk, R.K., Buser, D., \& Cochran, D. L. (2001). Influence of the size of the microgap on crestal bone changes around titanium implants. A histomorphometric evaluation of unloaded non-submerged implants in the canine mandible. Journal of Periodontology, 2, 1372-1383. https://doi:10.1902/jop.2001.72.10.1372

Isidor, F. (2006). Influence of forces on peri-implant bone. Clinical Oral Implants Research, Oct 17, Suppl 2, 8-18. https://doi:10.1111/j.1600-0501.2006.01360.x 
Jacobs, R., Pittayapat, P., van Steenberghe, D., De Mars, G., Gijbels, F., Van Der Donck, A., Li, L., Liang, X., Van Assche, N., Quirynen, M., \& Naert, I. (2010). A split-mouth comparative study up to 16 years of two screw-shaped titanium implant systems. Journal of Clinical Periodontology, 37, 1119-1127. https://doi:10.1111/j.1600-051X.2010.,01626.X Jansen, V. K., Conrads, G., \& Richter, E-J.. (1997). Microbial leakage and marginal fit of the implant-abutment interface. The International Journal of Oral and Maxillofacial Implants, 12 (4):527-540. PMID: 9274082.

Karl, M., Graef, F., \&Winter, W. (2015). Determination of micromotion at the implant bone interface - an in vitro methodologic study. Dentistry, 5, 289. https://doi:10.4172/2161$\underline{1122.1000289}$

Karl, M., Palarie, V., Chele, N., Steiner, C., Grobecker-Karl, T. (2018). Micromotion phenomena at the implant bone interface: a biomechanical and histomorphometric study. Journal of Dental and Maxillofacial Surgery. 1(1), 1. https://doi.org/10.18314/jdms.v1i1.1242

Kieswetter, K., Schwartz, Z., Hummert, T. W., Cochran, D.L., Simpson, J., Dean, D. D., \& Boyan, D. (1996). Surface roughness modulates the local production of growth factors and cytokines by osteoblast-like MG-63 cells. Journal of Biomedical Research, 32, 155-63.

Kitagawa, T., Tanimoto,Y., Odaki, M., Nemoto, K., \& Aida, M. (2005). Influence of implant/abutment joint designs on abutment screw loosening in a dental implant system. Journal of Biomedical Materials Research Part B: Applied Biomaterials, 75B:457-463.

https://doi:10.1002/jbm.b.30328

Klokkevold, P. R., Nishimura, R. D., \& Adachi, M. C. (1997). Osseointegration enhanced by chemical etching of the titanium surface. Clinical Oral Implants Research, 8, 442-447. https://doi:10.1034/j.1600-0501.1997.080601.x

Lekholm, U., Zarb, G. A. (1987). Patient selection and preparation. In: Brånemark, P-I., Zarb, G.A., Albrektsson, T. (Eds.). Tissue-integrated prostheses: osseointegration in clinical dentistry (pp. 175-285). Quintessence Publishing Co. Inc.

Li, Z., Gao, S., Chen, H., Ma, R., Wu, T., \& Yu, H. (2019). Micromotion of implant-abutment interfaces (IAI) after loading: correlation of finite element with in vitro performances. Journal of Medical and Biological Engineering and Computing, 57, 1133-1144.

https://doi.org/10.1007/s11517-018-1937-6 
Limbert, G., van Lierde, C., Muraru, O. L., Walboomers, F., Frank, M., Hansson, S., Middleton, J., \& Jaecques, S. (2010). Trabecular bone strains around a dental implant and associated micromotions - a micro-CT-based three-dimensional finite element study. Journal of Biomechanics, 43, 1251-1261. https://doi:10.1016/j.jbiomech.2010.01.003

Meijer, .H. J. A., Raghoebar, G. M., de Waal, Y. C. M., \& Vissink, A. (2014). Incidence of periimplant mucositis and peri-implantitis in edentulous patients with an implant-retained mandibular overdenture during a 10-year follow-up period. Journal of Clinical Periodontology, 41, 11781183. https://doi:10.1111/jcpe.12311

Moher, D. M., Hopewell, S., Schulz, K. F., et al. (2010). CONSORT Explanation and Elaboration: updated guidelines for reporting parallel group randomised trials. Journal of Clinical Epidemiology, 63, e1-e7. https://doi:10.1016/j.jclinepi.2010.03.004

Mombelli, A., Van Oosten, M. A. C., Schürch, E., \& Lang, N. P. (1987). The microbiota associated with successful or failing osseointegrated titanium implants. Oral Microbiology and Immunology, 82, 145-151. https://doi:10.1111/j.1399-302x.1987.tb00298.x

Niznick, G. A. (1989). Open letters no. 1 and no. 2 to the dental profession, Core-Vent Corporation Newsletter and manufacturer's product description. Encino, California USA.

Norton, M. R. (1997). An in vitro evaluation of the strength of an internal conical interface compared to a butt joint interface in implant design. Clinical Oral Implants Research, 8, 290-298. https://doi:10.1034/j.1600-0501.1997.080407.x

Quirynen, M., Naert, I., van Steenberghe, D., Duchateau, L., \& Darius, P. (1992). Periodontal aspects of Brånemark and IMZ implants supporting overdentures: A comparative study. In: W.R. Laney, D.E. Tolman (Eds.). Proceedings of the Second International Congress on Tissue Integration (pp. 80-93), Quintessence Publishing Co. Inc.

Quirynen, M., \& van Steenberghe, D. (1993). Bacterial colonization of the internal part of twostage implants. An in vivo study. Clinical Oral Implants Research, 4, 158-161.

Ravald, N., Dahlgren, S., Teiwik, A., \& Gröndahl, K. (2013). Long-term evaluation of Astra Tech and Brånemark implants in patients with full-arch bridges. Results after 12-15 years. Clinical Oral Implants Research, 2, 1144-1151. https://doi:10.1111/j.1600-0501.2012.02524.x 
Roos-Jansåker, A-M., Lindahl, C., Renvert, H., \& Renvert, S. (2006). Nine- to fourteen-year follow-up of implant treatment. Part I: implant loss and associations to various factors. Journal of Clinical Periodontology, 33, 283-289. https://doi:10.1111/j.1600-051X.2006.00907.x

Schroeder, A., van der Zypen, E., Stitch, H., \& Sutter, F. (1981). The reactions of bone, connective tissue, and epithelium to endosteal implants with titanium-sprayed surfaces. Journal of Oral and Maxillofacial Surgery, 9, 15-25. https://doi:10.1016/s0301-0503(81)80007-0

Sutter, F., Weber, H. P., Sorensen, J., \& Belser, U. (1993). The new restorative concept of the ITI dental implant system design and engineering. International Journal of Periodontics and Restorative Dentistry, 13(5), 409-431.

Szmukler-Montcler, S., Salama, H., Reingewirtz, Y., \& Dubruille, J. H. (1998). Timing of loading and effect of micromotion on bone-dental implant interface: review of experimental literature. The Journal of Biomedical Materials Research, Summer, 43(2), 192-203. https://doi:10.1002/(sici)1097-4636(199822)43:2<192::aid-jbm14>3.0.co;2-k

Tan, W. C., Lang, N. P., Schmidlin, K., Zwahlen, M., \& Pjetursson, B. E. (2011). The effect of different implant neck configurations on soft and hard tissue healing: a randomized-controlled clinical trial. Clinical Oral Implants Research, 22, 14-19. https://doi:10.1111/j.16000501.2010.01982.x

Thomas, K. A., \& Cook, S. D. (1985). An evaluation of variables influencing implant fixation by direct bone apposition. The Journal of Biomedical Materials Research, 19, 875-901. https://doi:10.1002/jbm.820190802.

Weber, H. P., Buser, D., Donath, K., Fiorinelli, J. P., Doppalapudi, V, Paquette, D. W., \& Williams, R. C. (1996). Comparison of healed tissue adjacent to submerged and non-submerged unloaded titanium dental implants. A histomorphometric study in beagle dogs. linical Oral Implants Research, 7, 11-19. https://doi:10.1034/j.1600-0501.1996.070102.x

Weng, D., Nagata, M. J. H., Bell, M., Nascimento de Melo, L. G., \& Bosco, A. F. (2010). Influence of microgap location and configuration on peri-implant bone morphology in nonsubmerged implants: an experimental study in dogs. The International Journal of Oral and Maxillofacial Implants, 25(3), 540-547. PMID:20556253. 
Wennerberg, A., Albrektsson, T., \& Andersson, B. (1993). Design and surface characteristics of 13 commercially available oral implant systems. The International Journal of Oral and Maxillofacial Implants, 8(6), 622-633. PMID: 8181824.

Wennerberg, A., Albrektsson, T., \& Andersson, B. (1996). Bone tissue response to commercially pure titanium implants blasted with fine and coarse particles of aluminum oxide. The International Journal of Oral and Maxillofacial Implants, 11(1), 38-45. PMID:8820121.

Wilke, H. J., Claes, L., \& Steinemann, S. (1990). The influence of various titanium surfaces on the interface shear strength between implants and bone. Clinical Implant Materials. In: Heimke, G., Solstéz, U., \& Lee, A. J. C. (Eds.). Advances in Biomaterials (vol. 9, pp.309-314), Elsevier Publishers BV.

Winter, W., Klein, D., \& Karl, M. (2013). Effect of model parameters on finite element analysis of micromotions in implant dentistry. Journal of Oral Implantology, 39(1), 23-29.

https://doi.org/10.1563/AAID/JOI/D-11-00221

Winter, W., Klein, D., \& Matthias, K. (2013). Micromotion of dental implants: basic mechanical considerations. Journal of Medical Engineering, 2013, Article ID 265412 (9 pages).

https://dx.doi.org/10.1155/2013/265412 